Acta Crystallographica Section E

Structure Reports

Online

ISSN 1600-5368

\section{Gary S. Nichol and William Clegg*}

School of Natural Sciences (Chemistry), Bedson Building, University of Newcastle, Newcastle upon Tyne NE1 7RU, England

Correspondence e-mail: w.clegg@ncl.ac.uk

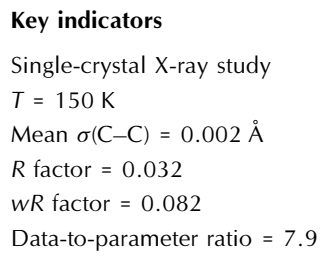

Key indicators

Single-crystal X-ray study

$T=150 \mathrm{~K}$

Mean $\sigma(\mathrm{C}-\mathrm{C})=0.002 \AA$

$R$ factor $=0.032$

$w R$ factor $=0.082$

Data-to-parameter ratio $=7.9$

For details of how these key indicators were automatically derived from the article, see http://journals.iucr.org/e.

\title{
Malonamide: a tetragonal polymorph
}

A tetragonal polymorph of malonamide, $\mathrm{C}_{3} \mathrm{H}_{6} \mathrm{~N}_{2} \mathrm{O}_{2}$, is reported. The unit-cell dimensions, crystallographic symmetry and some aspects of the molecular geometry are significantly different from those of the known monoclinic form [Chieh et al. (1970). J. Chem. Soc. A, pp. 179-184]. An $R_{3}^{3}(12)$ hydrogenbonding motif links molecules together into a three-dimensional network.

\section{Comment}

Crystals of malonamide, (I), were obtained from a reaction between 4,6-dihydroxypyrimidine and $\mathrm{Na}_{2} \mathrm{CO}_{3}$ in water. Data collected at $150 \mathrm{~K}$ showed that it had crystallized in space group $P 4_{3} 2_{1} 2$ with $Z^{\prime}=0.5$ and $Z=4$. It was only some time after structure solution that, by carrying out a search of the Cambridge Structural Database (CSD, Version 5.26; Allen, 2002), we realised a crystal structure of malonamide had previously been reported (Chieh et al., 1970) in space group $P 2_{1} / c$ with two independent molecules in the asymmetric unit and a final $R=0.05$. This indicates either that the structure undergoes a phase transition above $150 \mathrm{~K}$ or that we had identified a second polymorph. However, by the time this was realized the original crystalline sample had been lost, although the original aqueous solution remained. In an attempt to answer this question we crystallized more of the product, with the intention of carrying out unit-cell determinations at $150 \mathrm{~K}$ and room temperature in order to show any phase transition. What we actually determined was a further, orthorhombic, polymorph of (I), described in the following paper (Nichol \& Clegg, 2005). This third polymorph did not undergo a phase transition between room temperature and $150 \mathrm{~K}$ and, based on this observation, we are satisfied that the structure presented here is probably a genuine polymorph and not the consequence of a phase transition from the previously reported form as a result of cooling.<smiles>NC(=O)CC(N)=O</smiles>

(I)

The molecular structure of (I) is shown in Fig. 1. The asymmetric unit consists of one half of the molecule, and the complete molecule is generated from the asymmetric unit by a twofold axis which passes through $\mathrm{C} 2$. Bond lengths and angles are in good agreement with the mean values reported by Chieh et al. (1970); however, the torsion angle about the $\mathrm{C} 1-\mathrm{C} 2$ bond is significantly different. Fig. 2 shows a wire-
Received 21 September 2005 Accepted 23 September 2005 Online 28 September 2005
(C) 2005 International Union of Crystallography Printed in Great Britain - all rights reserved 


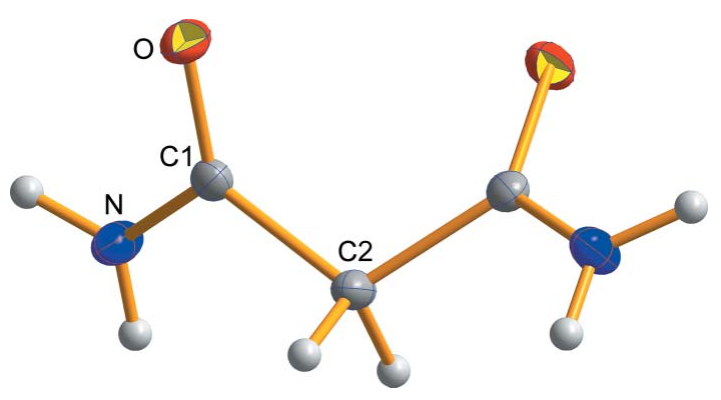

Figure 1

The molecular structure of (I), with displacement ellipsoids drawn at the $50 \%$ probability level and $\mathrm{H}$ atoms as small spheres. The labelled atoms indicate the asymmetric unit; the molecule is generated by a twofold rotation axis $(y, x,-z)$ which passes through $\mathrm{C} 2$.

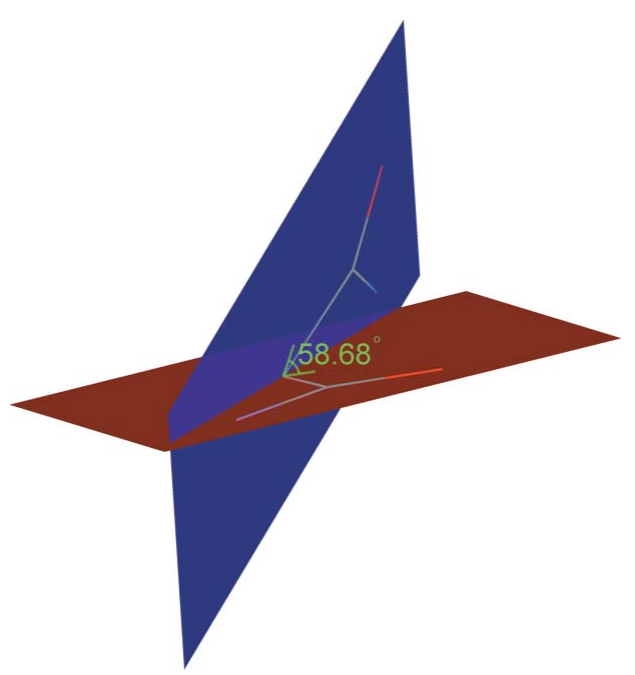

Figure 2

Two mean planes, one drawn through $\mathrm{N}, \mathrm{O}, \mathrm{C} 1$ and $\mathrm{C} 2$ and the other through their symmetry equivalents, and the dihedral angle between the two planes.

frame diagram of (I) with two mean planes fitted through $\mathrm{O}, \mathrm{N}$, $\mathrm{C} 1$ and $\mathrm{C} 2$ and through the respective symmetry equivalents. Both planes intersect at $\mathrm{C} 2$ and the angle between the two planes is $58.68(4)^{\circ}$. This value is over $27^{\circ}$ less than the angles reported by Chieh et al. (1970) for both independent molecules $\left(84.8\right.$ and $\left.85.3^{\circ}\right)$.

Fig. 3 shows a packing diagram viewed along the $b$ axis. What initially looks like a complicated network is actually the result of just two independent $\mathrm{N}-\mathrm{H}$... O hydrogen bonds (one for each of the amino $\mathrm{H}$ atoms), with the $\mathrm{O}$ atom acting as a bifurcated acceptor. The result of this is a three-dimensional network of $R_{3}^{3}(12)$ hydrogen-bonding motifs, illustrated in Fig. 4 (Etter, 1990; Bernstein et al., 1995).

\section{Experimental}

Equimolar amounts of 4,6-dihydroxypyrimidine and $\mathrm{Na}_{2} \mathrm{CO}_{3}$ were dissolved in $20 \mathrm{ml}$ of hot distilled water, forming a pale-yellow solution. Large plate-shaped crystals of (I) were grown by slow evaporation of the cold solution on a watch glass over a period of approximately $5 \mathrm{~d}$.

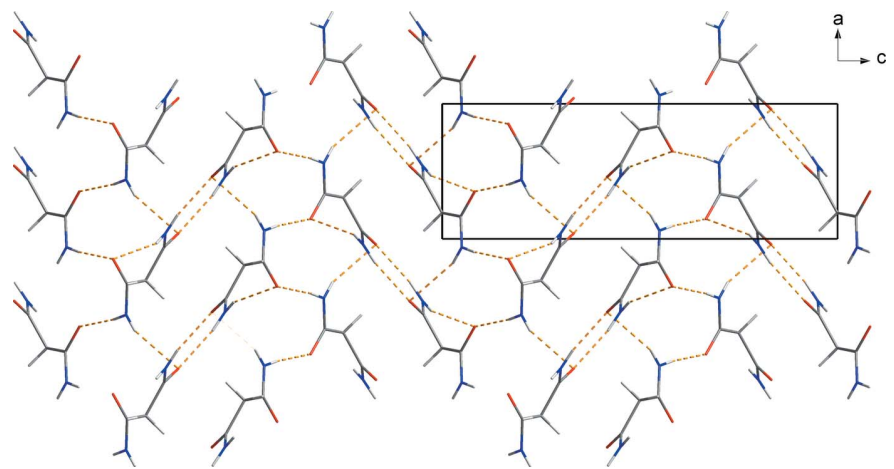

Figure 3

A packing diagram, viewed along the $b$ axis. Hydrogen bonds are indicated by orange dashed lines.

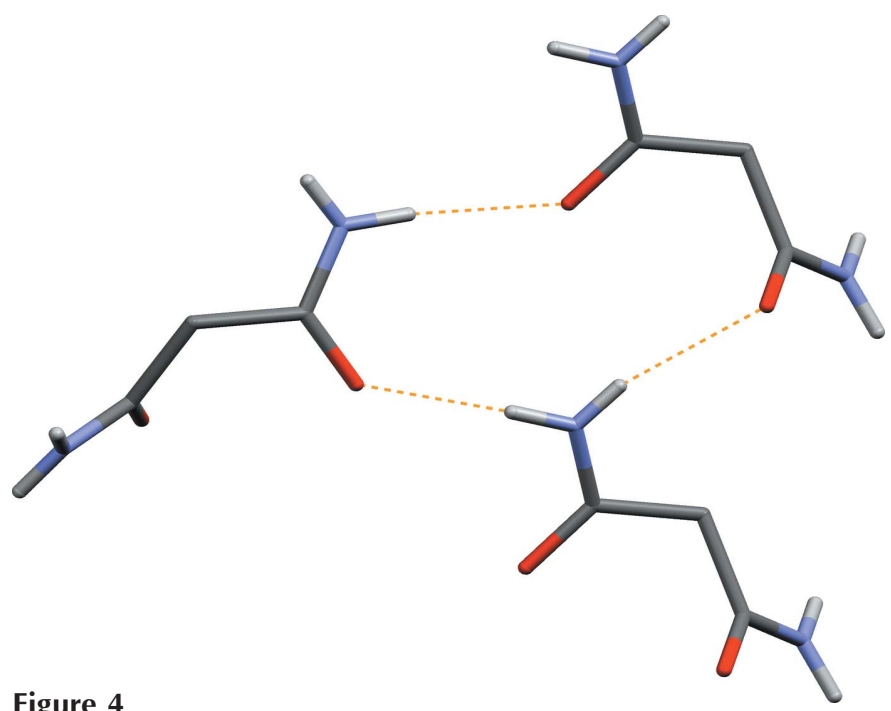

The $R_{3}^{3}(12)$ hydrogen-bonding motif. Hydrogen bonds are indicated by orange dashed lines and $\mathrm{C}$-bound $\mathrm{H}$ atoms are omitted.

\section{Crystal data}

$\mathrm{C}_{3} \mathrm{H}_{6} \mathrm{~N}_{2} \mathrm{O}_{2}$

$M_{r}=102.10$

Tetragonal, $P 4_{3} 2_{1} 2$

$a=5.3140$ (3) А

$c=15.5360(12) \AA$

$V=438.71(5) \AA^{3}$

$Z=4$

$D_{x}=1.546 \mathrm{Mg} \mathrm{m}^{-3}$

Data collection

Nonius KappaCCD diffractometer $\varphi$ and $\omega$ scans

Absorption correction: multi-scan (SADABS; Sheldrick, 2003)

$T_{\min }=0.902, T_{\max }=0.997$

6874 measured reflections

340 independent reflections

Refinement

Refinement on $F^{2}$

$R\left[F^{2}>2 \sigma\left(F^{2}\right)\right]=0.032$

$w R\left(F^{2}\right)=0.082$

$S=1.23$

340 reflections

43 parameters

Only $\mathrm{H}$-atom coordinates refined

\author{
Mo $K \alpha$ radiation \\ Cell parameters from 54 \\ reflections \\ $\theta=2.5-27.5^{\circ}$ \\ $\mu=0.13 \mathrm{~mm}^{-1}$ \\ $T=150$ (2) $\mathrm{K}$ \\ Plate, light yellow \\ $0.50 \times 0.50 \times 0.02 \mathrm{~mm}$
}

324 reflections with $I>2 \sigma(I)$

$R_{\text {int }}=0.018$

$\theta_{\max }=27.5^{\circ}$

$h=-6 \rightarrow 6$

$k=-5 \rightarrow 6$

$l=-20 \rightarrow 20$ 
Table 1

Selected geometric parameters $\left(\AA{ }^{\circ}\right)$.

\begin{tabular}{llll}
\hline $\mathrm{O}-\mathrm{C} 1$ & $1.2382(17)$ & $\mathrm{C} 1-\mathrm{C} 2$ & $1.5176(17)$ \\
$\mathrm{N}-\mathrm{C} 1$ & $1.3251(19)$ & & \\
$\mathrm{O}-\mathrm{C} 1-\mathrm{C} 2-\mathrm{Cl}^{\mathrm{i}}$ & $-36.66(9)$ & $\mathrm{N}-\mathrm{C} 1-\mathrm{C} 2-\mathrm{Cl}^{\mathrm{i}}$ & $145.23(12)$ \\
\hline
\end{tabular}

Symmetry code: (i) $y, x,-z$.

Table 2

Hydrogen-bond geometry $\left(\AA,^{\circ}\right)$.

\begin{tabular}{lllll}
\hline$D-\mathrm{H} \cdots A$ & $D-\mathrm{H}$ & $\mathrm{H} \cdots A$ & $D \cdots A$ & $D-\mathrm{H} \cdots A$ \\
\hline $\mathrm{N}-\mathrm{H} 1 N \cdots \mathrm{O}^{\mathrm{ii}}$ & $0.87(2)$ & $2.05(2)$ & $2.9195(16)$ & $171(2)$ \\
$\mathrm{N}-\mathrm{H} 2 N \cdots \mathrm{O}^{\mathrm{iii}}$ & $0.79(2)$ & $2.36(2)$ & $3.1112(17)$ & $158(2)$
\end{tabular}

Symmetry codes: (ii) $x-\frac{1}{2},-y+\frac{3}{2},-z+\frac{1}{4}$; (iii) $y-1, x,-z$.

All $\mathrm{H}$ atoms were located in a difference map and their coordinates were refined freely, with $U_{\text {iso }}(\mathrm{H})=1.2 U_{\text {eq }}(\mathrm{N}, \mathrm{C})$. The $\mathrm{C}-\mathrm{H}$ bond length refined to 0.986 (19) $\AA$ and the two $\mathrm{N}-\mathrm{H}$ bond lengths refined to 0.87 (2) and 0.79 (2) A. Friedel pairs were merged during the final refinement cycles due to the lack of significant anomalous dispersion; the choice of chiral space group $P 4_{3} 2_{1} 2$ rather than $P 4_{1} 2_{1} 2$ is arbitrary.

Data collection: COLLECT (Nonius, 1998); cell refinement: DIRAX (Duisenberg, 1992); data reduction: EVALCCD (Duisen- berg et al., 2003); program(s) used to solve structure: SIR2002 (Burla et al., 2003); program(s) used to refine structure: SHELXTL (Sheldrick, 2001); molecular graphics: DIAMOND3 (Brandenburg \& Putz, 2004) and MERCURY (Version 1.3; Bruno et al., 2002); software used to prepare material for publication: SHELXTL and local programs.

The authors thank the EPSRC for funding.

\section{References}

Allen, F. H. (2002). Acta Cryst. B58, 380-388.

Bernstein, J., Davis, R. E., Shimoni, L. \& Chang, N.-L. (1995). Angew. Chem. Int. Ed. Engl. 34, 1555-1573.

Brandenburg, K. \& Putz, H. (2004). DIAMOND3. University of Bonn, Germany.

Bruno, I. J., Cole, J. C., Edgington, P. R., Kessler, M., Macrae, C. F., McCabe, P., Pearson, J. \& Taylor, R. (2002). Acta Cryst. B58, 389-397.

Burla, M. C., Camalli, M., Carrozzini, B., Cascarano, G. L., Giacovazzo, C., Polidori, G. \& Spagna, R. J. (2003). Appl. Cryst. 36, 1103.

Chieh, P. C., Subramanian, E. \& Trotter, J. (1970). J. Chem. Soc. A, pp. 179184.

Duisenberg, A. J. M. (1992). J. Appl. Cryst. 25, 92-96.

Duisenberg, A. J. M., Kroon-Batenburg, L. M. J. \& Schreurs, A. M. M. (2003). J. Appl. Cryst. 36, 220-229.

Etter, M. C. (1990). Acc. Chem. Res. 23, 120-126.

Nichol, G. S. \& Clegg, W. (2005). Acta Cryst. E61, o3427-o3429.

Nonius (1998). COLLECT. Nonius BV, Delft, The Netherlands.

Sheldrick, G. M. (2001). SHELXTL. Version 6. Bruker AXS Inc., Madison, Wisconsin, USA.

Sheldrick, G. M. (2003). SADABS. University of Göttingen, Germany. 


\section{supporting information}

Acta Cryst. (2005). E61, o3424-03426 [doi:10.1107/S1600536805030539]

\section{Malonamide: a tetragonal polymorph}

\section{Gary S. Nichol and William Clegg}

\section{S1. Comment}

Crystals of malonamide, (I), were obtained from a reaction between 4,6-dihydroxypyrimidine and $\mathrm{Na}_{2} \mathrm{CO}_{3}$ in water. Data collected at $150 \mathrm{~K}$ showed that it had crystallized in space group $P 4_{3} 2_{1} 2$ with $Z^{\prime}=0.5$ and $Z=4$. It was only some time after structure solution that, by carrying out a search of the Cambridge Structural Database (CSD, Version 5.26; Allen, 2002), we realised a crystal structure of malonamide had previously been reported (Chieh et al., 1970) in space group $P 2_{1} / c$ with two independent molecules in the asymmetric unit and a final $R=0.05$. This indicates either that the structure undergoes a phase transition above $150 \mathrm{~K}$ or that we had identified a second polymorph. However, by the time this was realised the original crystalline sample had been lost, although the original aqueous solution remained. In an attempt to answer this question we crystallized more of the product, with the intention of carrying out unit-cell determinations at $150 \mathrm{~K}$ and room temperature in order to show any phase transition. What we actually determined was a further, orthorhombic, polymorph of (I), described in the following paper (Nichol \& Clegg, 2005). This third polymorph did not undergo a phase transition between room temperature and $150 \mathrm{~K}$ and, based on this observation, we are satisfied that the structure presented here is probably a genuine polymorph and not the consequence of a phase transition from the previously reported form as a result of cooling.

The molecular structure of (I) is shown in Fig. 1. The asymmetric unit consists of one half of the molecule, and the complete molecule is generated from the asymmetric unit by a twofold axis which passes through $\mathrm{C} 2$. Bond lengths and angles are in good agreement with the mean values reported by Chieh et al. (1970); however, the torsion angle about the $\mathrm{C} 1-\mathrm{C} 2$ bond is significantly different. Fig. 2 shows a wireframe diagram of (I) with two mean planes fitted through $\mathrm{O}$, $\mathrm{N}, \mathrm{C} 1$ and $\mathrm{C} 2$ and through the respective symmetry equivalents. Both planes intersect at $\mathrm{C} 2$ and the angle between the two planes is $58.68(4)^{\circ}$. This value is over $27^{\circ}$ less than the angles reported by Chieh et al. (1970) for both independent molecules $\left(84.8\right.$ and $\left.85.3^{\circ}\right)$.

Fig. 3 shows a packing diagram viewed along the $b$ axis. What initially looks like a complicated network is actually the result of just two independent $\mathrm{N}-\mathrm{H} \cdots \mathrm{O}$ hydrogen bonds (one for each of the amino $\mathrm{H}$ atoms), with the $\mathrm{O}$ atom acting as a bifurcated acceptor. The result of this is a three-dimensional network of $R_{3}^{3}(12)$ hydrogen-bonding motifs, illustrated in Fig. 4 (Etter, 1990; Bernstein et al., 1995).

\section{S2. Experimental}

Equimolar amounts of 4,6-dihydroxypyrimidine and $\mathrm{Na}_{2} \mathrm{CO}_{3}$ were dissolved in $20 \mathrm{ml}$ of hot distilled water, forming a pale-yellow solution. Large plate-shaped crystals of (I) were grown by slow evaporation of the cold solution on a watch glass over a period of approximately $5 \mathrm{~d}$. 


\section{supporting information}

\section{S3. Refinement}

All $\mathrm{H}$ atoms were located in a difference map and their coordinates were refined freely, with $U_{\text {iso }}(\mathrm{H})=1.2 U_{\text {eq }}(\mathrm{N}, C)$. The $\mathrm{C}$ $-\mathrm{H}$ bond length refined to 0.986 (19) $\AA$ and the two $\mathrm{N}-\mathrm{H}$ bond lengths refined to 0.87 (2) and 0.79 (2) $\AA$. Friedel pairs were merged during the final refinement cycles due to the lack of significant anomalous dispersion.

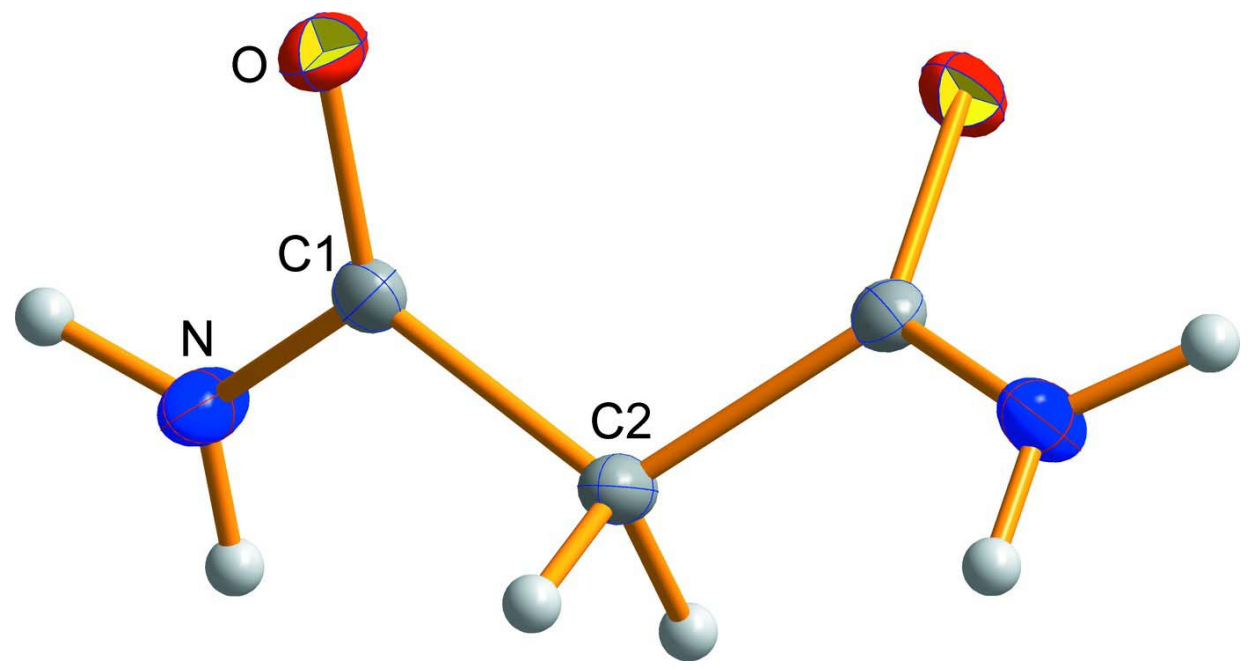

\section{Figure 1}

The molecular structure of (I), with displacement ellipsoids drawn at the $50 \%$ probability level and $\mathrm{H}$ atoms as small spheres. The labelled atoms indicate the asymmetric unit; the molecule is generated by a twofold rotation axis $(y, x,-z)$ which passes through $\mathrm{C} 2$. 


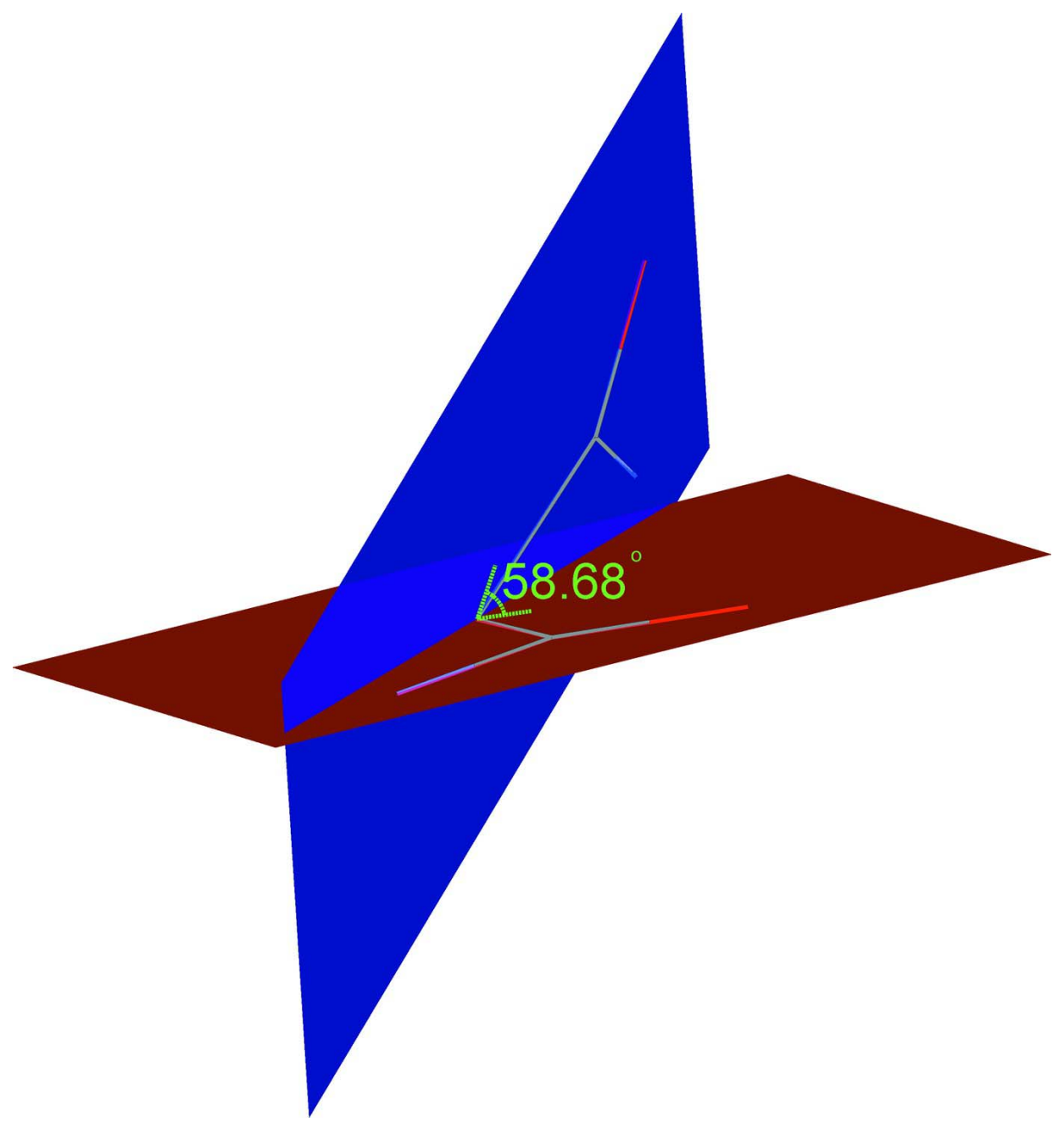

\section{Figure 2}

Two mean planes, one drawn through $\mathrm{N}, \mathrm{O}, \mathrm{C} 1$ and $\mathrm{C} 2$ and the other through their symmetry equivalents, and the dihedral angle between the two planes. 


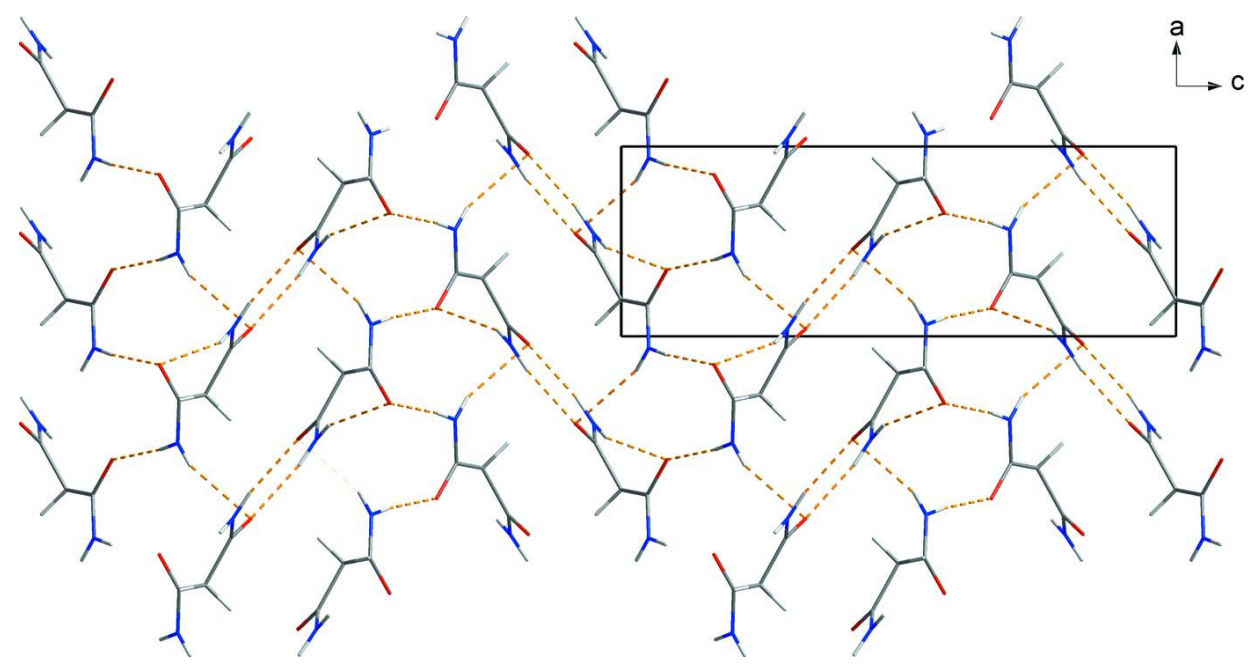

\section{Figure 3}

A packing diagram, viewed along the $b$ axis. Hydrogen bonds are indicated by orange dashed lines.

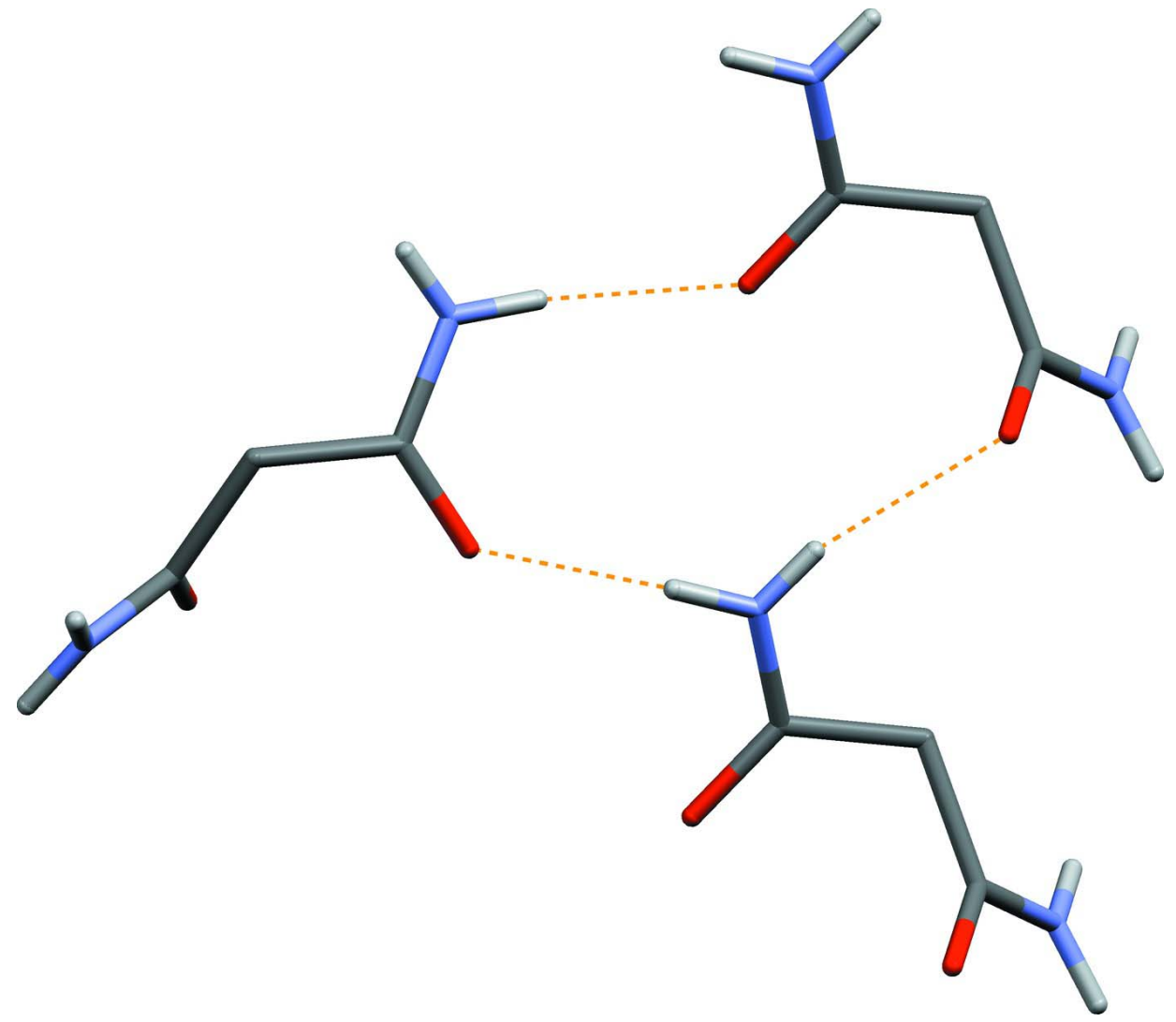

\section{Figure 4}

The $R_{3}{ }^{3}(12)$ hydrogen-bonding motif. Hydrogen bonds are indicated by orange dashed lines and C-bound $\mathrm{H}$ atoms are omitted. 


\section{Malonamide}

Crystal data

$\mathrm{C}_{3} \mathrm{H}_{6} \mathrm{~N}_{2} \mathrm{O}_{2}$

$M_{r}=102.10$

Tetragonal, $P 4_{3} 2_{1} 2$

Hall symbol: P 4nw 2abw

$a=5.3140(3) \AA$

$c=15.5360(12) \AA$

$V=438.71(5) \AA^{3}$

$Z=4$

$F(000)=216$

Data collection

Nonius KappaCCD diffractometer

Radiation source: sealed tube

Graphite monochromator

$\varphi$ and $\omega$ scans

Absorption correction: multi-scan

(SADABS; Sheldrick, 2003)

$T_{\min }=0.902, T_{\max }=0.997$

\section{Refinement}

Refinement on $F^{2}$

Least-squares matrix: full

$R\left[F^{2}>2 \sigma\left(F^{2}\right)\right]=0.032$

$w R\left(F^{2}\right)=0.082$

$S=1.23$

340 reflections

43 parameters

0 restraints

Primary atom site location: structure-invariant direct methods
$D_{\mathrm{x}}=1.546 \mathrm{Mg} \mathrm{m}^{-3}$

Mo $K \alpha$ radiation, $\lambda=0.71073 \AA$

Cell parameters from 54 reflections

$\theta=2.5-27.5^{\circ}$

$\mu=0.13 \mathrm{~mm}^{-1}$

$T=150 \mathrm{~K}$

Block, light yellow

$0.50 \times 0.50 \times 0.02 \mathrm{~mm}$

6874 measured reflections

340 independent reflections

324 reflections with $I>2 \sigma(I)$

$R_{\text {int }}=0.018$

$\theta_{\max }=27.5^{\circ}, \theta_{\min }=5.3^{\circ}$

$h=-6 \rightarrow 6$

$k=-5 \rightarrow 6$

$l=-20 \rightarrow 20$

Secondary atom site location: difference Fourier map

Hydrogen site location: difference Fourier map

Only $\mathrm{H}$-atom coordinates refined

$w=1 /\left[\sigma^{2}\left(F_{\mathrm{o}}^{2}\right)+(0.0509 P)^{2}+0.0691 P\right]$

where $P=\left(F_{\mathrm{o}}{ }^{2}+2 F_{\mathrm{c}}{ }^{2}\right) / 3$

$(\Delta / \sigma)_{\max }<0.001$

$\Delta \rho_{\max }=0.19 \mathrm{e} \AA^{-3}$

$\Delta \rho_{\min }=-0.20$ e $\AA^{-3}$

Extinction correction: SHELXL97, $\mathrm{Fc}^{*}=\mathrm{kFc}\left[1+0.001 \mathrm{xFc}^{2} \lambda^{3} / \sin (2 \theta)\right]^{-1 / 4}$

Extinction coefficient: $0.12(3)$

\section{Special details}

Geometry. All e.s.d.'s (except the e.s.d. in the dihedral angle between two 1.s. planes) are estimated using the full covariance matrix. The cell e.s.d.'s are taken into account individually in the estimation of e.s.d.'s in distances, angles and torsion angles; correlations between e.s.d.'s in cell parameters are only used when they are defined by crystal symmetry. An approximate (isotropic) treatment of cell e.s.d.'s is used for estimating e.s.d.'s involving 1.s. planes.

Fractional atomic coordinates and isotropic or equivalent isotropic displacement parameters $\left(\AA^{2}\right)$

\begin{tabular}{lllll}
\hline & $x$ & $y$ & $z$ & $U_{\text {iso }} / U_{\text {eq }}$ \\
\hline $\mathrm{O}$ & $0.35135(18)$ & $0.5410(2)$ & $0.08252(5)$ & $0.0193(4)$ \\
$\mathrm{N}$ & $-0.0616(2)$ & $0.5402(3)$ & $0.04955(8)$ & $0.0182(4)$ \\
$\mathrm{H} 1 \mathrm{~N}$ & $-0.095(4)$ & $0.675(4)$ & $0.0800(11)$ & $0.022^{*}$ \\
$\mathrm{H} 2 \mathrm{~N}$ & $-0.177(4)$ & $0.469(4)$ & $0.0277(12)$ & $0.022^{*}$ \\
$\mathrm{C} 1$ & $0.1676(3)$ & $0.4422(3)$ & $0.04704(8)$ & $0.0134(4)$ \\
$\mathrm{C} 2$ & $0.1932(2)$ & $0.1932(2)$ & 0.0000 & $0.0147(4)$ \\
$\mathrm{H} 2$ & $0.166(3)$ & $0.064(4)$ & $0.0448(10)$ & $0.018^{*}$ \\
\hline
\end{tabular}




\section{supporting information}

Atomic displacement parameters $\left(\AA^{2}\right)$

\begin{tabular}{lllllll}
\hline & $U^{11}$ & $U^{22}$ & $U^{33}$ & $U^{12}$ & $U^{13}$ & $U^{23}$ \\
\hline $\mathrm{O}$ & $0.0154(6)$ & $0.0201(6)$ & $0.0222(5)$ & $-0.0024(4)$ & $-0.0014(4)$ & $-0.0069(4)$ \\
$\mathrm{N}$ & $0.0137(7)$ & $0.0158(7)$ & $0.0252(7)$ & $0.0002(5)$ & $-0.0013(5)$ & $-0.0063(5)$ \\
$\mathrm{C} 1$ & $0.0148(7)$ & $0.0133(7)$ & $0.0121(5)$ & $-0.0017(5)$ & $0.0015(5)$ & $0.0008(5)$ \\
$\mathrm{C} 2$ & $0.0130(6)$ & $0.0130(6)$ & $0.0180(8)$ & $-0.0020(7)$ & $0.0020(5)$ & $-0.0020(5)$ \\
\hline
\end{tabular}

Geometric parameters $\left(A,{ }^{\circ}\right)$

\begin{tabular}{llll}
\hline $\mathrm{O}-\mathrm{C} 1$ & $1.2382(17)$ & $\mathrm{N}-\mathrm{C} 1$ & $1.3251(19)$ \\
$\mathrm{N}-\mathrm{H} 1 \mathrm{~N}$ & $0.87(2)$ & $\mathrm{C} 1-\mathrm{C} 2$ & $1.5176(17)$ \\
$\mathrm{N}-\mathrm{H} 2 \mathrm{~N}$ & $0.79(2)$ & $\mathrm{C} 2-\mathrm{H} 2$ & $0.986(19)$ \\
& $117(2)$ & $\mathrm{N}-\mathrm{C} 1-\mathrm{C} 2$ & $116.07(11)$ \\
$\mathrm{H} 1 \mathrm{~N}-\mathrm{N}-\mathrm{H} 2 \mathrm{~N}$ & $121.7(13)$ & $\mathrm{C} 1-\mathrm{C} 2-\mathrm{C} 1^{\mathrm{i}}$ & $112.84(16)$ \\
$\mathrm{H} 1 \mathrm{~N}-\mathrm{N}-\mathrm{C} 1$ & $120.5(15)$ & $\mathrm{C} 1-\mathrm{C} 2-\mathrm{H} 2$ & $104.6(10)$ \\
$\mathrm{H} 2 \mathrm{~N}-\mathrm{N}-\mathrm{C} 1$ & $123.02(13)$ & $\mathrm{C} 1-\mathrm{C} 2-\mathrm{H} 2$ & $113.9(11)$ \\
$\mathrm{O}-\mathrm{C} 1-\mathrm{N}$ & $120.88(12)$ & & \\
$\mathrm{O}-\mathrm{C} 1-\mathrm{C} 2$ & $-36.66(9)$ & $\mathrm{N}-\mathrm{C} 1-\mathrm{C} 2-\mathrm{Cl}^{\mathrm{i}}$ & $145.23(12)$ \\
$\mathrm{O}-\mathrm{C} 1-\mathrm{C} 2-\mathrm{C} 1^{\mathrm{i}}$ & &
\end{tabular}

Symmetry code: (i) $y, x,-z$.

Hydrogen-bond geometry $\left(\AA,{ }^{\circ}\right)$

\begin{tabular}{lllll}
\hline$D-\mathrm{H} \cdots A$ & $D-\mathrm{H}$ & $\mathrm{H} \cdots A$ & $D \cdots A$ & $D-\mathrm{H} \cdots A$ \\
\hline $\mathrm{N}-\mathrm{H} 1 N \cdots \mathrm{O}^{\mathrm{ii}}$ & $0.87(2)$ & $2.05(2)$ & $2.9195(16)$ & $170.8(16)$ \\
$\mathrm{N}-\mathrm{H} 2 N \cdots \mathrm{O}^{\mathrm{iii}}$ & $0.79(2)$ & $2.36(2)$ & $3.1112(17)$ & $157.6(19)$ \\
\hline
\end{tabular}

Symmetry codes: (ii) $x-1 / 2,-y+3 / 2,-z+1 / 4$; (iii) $y-1, x,-z$. 